"Customs duty incentives and their effects on customs revenue mobilization: the case of Zimbabwe (2009-2014)"

\begin{tabular}{|c|c|c|}
\hline AUTHORS & Ezera Madzivanyika & \\
\hline ARTICLE INFO & $\begin{array}{l}\text { Ezera Madzivanyika (2016). Cus } \\
\text { customs revenue mobilization: t } \\
\text { Municipal Finance, } 5(1), 6-13 \text {. d }\end{array}$ & $\begin{array}{l}\text { ses and their effects on } \\
\text { we (2009-2014). Public and } \\
\text { (1).2016.01 }\end{array}$ \\
\hline DOI & http://dx.doi.org/10.21511/pmf.0 & \\
\hline RELEASED ON & Tuesday, 19 July 2016 & \\
\hline JOURNAL & "Public and Municipal Finance" & \\
\hline FOUNDER & LLC "Consulting Publishing Cor & erspectives" \\
\hline & & $\begin{array}{l}\text { Ẽ } \\
\text { =E: }\end{array}$ \\
\hline NUMBER OF REFERENCES & NUMBER OF FIGURES & NUMBER OF TABLES \\
\hline
\end{tabular}

(C) The author(s) 2022. This publication is an open access article. 
Ezera Madzivanyika (Zimbabwe)

\title{
Customs duty incentives and their effects on customs revenue mobi- lization: the case of Zimbabwe (2009-2014)
}

\begin{abstract}
This paper analyzes the effects of customs duty incentives on customs revenue mobilization for the period 2009 to 2014. It employs both cross-sectional and panel data regression analysis using firm-level data obtained for a sample of 35 firms in Zimbabwe's mining sector. The data were collected from Zimbabwe Revenue Authority's Asycuda World System. The results from the two separate models confirm that customs duty incentives (rebates and preferential tariff rates) had negative effects on customs revenues for the period 2009 to 2014. The study, therefore, recommends an urgent need to streamline customs duty incentives granted to importers of goods meant for use in the mining sector.
\end{abstract}

Keywords: Customs duty incentives, mining sector, rebates, preferential tariff rates, Zimbabwe. JEL Classification: H2, H3, H5.

\section{Introduction}

Zimbabwe's fiscal policy is characterized by the existence of rampant tax incentives. However, these vast tax incentives are not translating into improved revenue collections, let alone better performance of those companies who are their recipients. There are companies which, after having enjoyed tax incentives for years, ended up closing shop in Zimbabwe, before the country reaped any positive benefits from them. The mining sector, with its vast resource endowments, is not contributing enough in terms of fiscal revenue.

Objectives. The study evaluates the effects of customs duty incentives available in Zimbabwe's mining sector. Customs duty incentives were evaluated in terms of their effects on exchequer revenue mobilization. Specifically, the objectives were as follows:

- To explore the nature of customs duty incentives available in Zimbabwe's mining sector.

- To evaluate the effects of customs duty incentives (rebates and preferential tariff rates) on customs duty collections for the period 2009 to 2014

- To analyze the relationship between imports' values and customs duty collections for the period 2009 to 2014.

Research questions. The key research questions were as follows:

- What are the general customs duty incentives and those specific to the mining sector of Zimbabwe?

- What are the effects of customs duty incentives on exchequer revenue mobilization?

(C) Ezera Madzivanyika, 2016.

Ezera Madzivanyika, University of Zimbabwe, Zimbabwe.

The results of the study reflect views of the author alone.

Acknowledgements to the "African Economic Research Consortium (AERC)" in Nairobi, Kenya who have awarded to the author a research grant to carry out the study.
- What is the relationship between customs duty and other trade taxes like Value Added Tax on imports?

- What is the relationship between customs duty and imports' values in Zimbabwe's mining sector?

Justification of the study. The study is essential for tax policy reform. The country is in a policy dilemma with regards to which mining model to adopt after realizing that the current mining taxation regime has done more harm than good for the economy. However, in the absence of empirical justification policy makers would find it difficult to adopt any new model for taxing the mining sector. The paper, therefore, intended to provide empirical evidence for scrapping or maintaining the existing customs duty regime in the mining sector.

There are also gaps that need to be filled in the literature on tax incentives, especially in developing economies like Zimbabwe. Due to lack of firm level data, most of the previous studies have covered a broad spectrum of tax incentives for a group of countries within a particular trading bloc, for example, Southern African Development Community (SADC) rather than concentrating on the intricacies of the tax system within a specific country. In addition, previous studies concentrated on Corporate Tax incentives, saying little about trade tax incentives. The study employed cross sectional and panel data regression analysis using firm level data obtained from Zimbabwe Revenue Authority's Asycuda World System.

Study outline. The paper is structured as follows: section 1 provides the background to the study, focusing on the general structure of customs Tariffs as well as customs duty rebates specific to the mining sector in Zimbabwe. Section 2 presents theoretical and empirical overviews of the literature on tax incentives. Section 3 presents the panel data and cross sectional regression analysis that were used in the study. The results of the estimated models are also presented and discussed in this Section. Final section concludes the study with a discussion of findings and policy recommendations. 


\section{Background to the study}

1.1. The structure of customs duty rates in Zimbabwe. Rates of customs duty, excise duty and surtax are set by the Minister of Finance and Economic Development by statutory instruments. The Minister of Finance and Economic Development's mandate is derived from the Customs \& Excise Act Chapter 23:02. The Minister can also prescribe, by way of regulations, any suspension, drawback, rebate, remission or refund of duty as may be deemed convenient. The Competition and Tariffs Commission, through the Minister of Industry and Commerce, advises the Minister of Finance and Economic Development on the setting of tariff rates and the granting of exemptions or concessions. The rates of Customs duty can be classified into most favored nations (MFN), preferential tariffs, rebates, remissions and suspensions. These are analyzed below.

1.1.1. MFN rates. Zimbabwe grants most favored nations (MFN) status to all its trading partners, including those that are not World Trade Organization
(WTO) members. In 2011, the applied MFN customs tariff which was based on the 2007 version of the Harmonized Commodity Description and Coding System (HS) comprised 5,932 lines at the 8-digit level. Almost $94 \%$ of all tariff lines, including dutyfree ones, had ad valorem rates, the remaining $6.1 \%$ carried either specific or compound rates. Most nonad valorem duties applied to certain imports of alcoholic beverages, tobacco, apparel and footwear.

Rates of customs duty varied depending on the nature of the product. The rates ranged from $0 \%$ to $60 \%$ of Value for Duty Purposes. Capital goods attracted lower rates of duty, usually between $0 \%$ and $5 \%$. On the other hand, raw materials attracted duty rates of between $5 \%$ and $10 \%$. Finished goods attracted rates of duty ranging above $10 \%$ to $60 \%$. Figure 1 shows a breakdown of the MFN tariff rates for the year 2011. About $36 \%$ of the imports were in the 0 to $5 \%$ tariff rates, while almost $10 \%$ of the imports did not pay any duty. On the other hand, $19 \%$ of the imports were levied customs duty at the rates of 35 to $40 \%$.

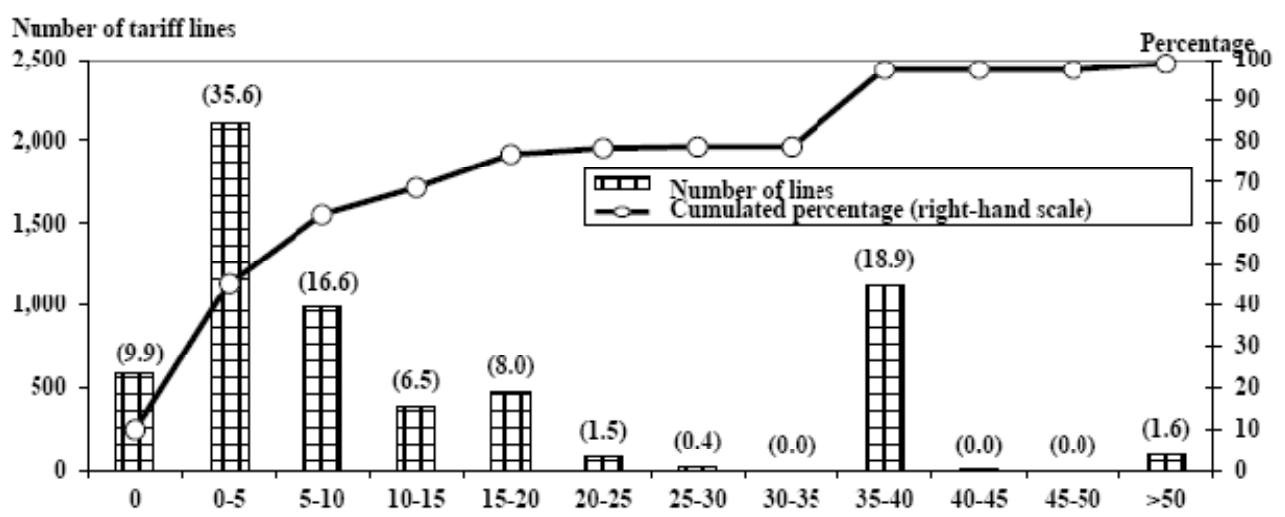

Fig. 1 Breakdown of Zimbabwe's applied MFN tariff rates in 2011

Source: Adapted from the World Trade Organization 2011 Report on Zimbabwe.

1.1.2. Preferential rates. Zimbabwe offers tariff preferences under bilateral and regional trade agreements. These trade agreements aim to encourage trade between Zimbabwe and the cooperating partner through the elimination of tariffs and nontariff barriers to trade. The agreement allows the Zimbabwean buyers to purchase goods from the cooperating countries without paying import duty (or paying duty at an agreed lower rate), as long as the goods qualify under the terms of the agreement and are registered with the Zimbabwe Revenue Authority.

Zimbabwe has bilateral trade agreements with Botswana, Namibia, Malawi, Mozambique and South Africa. The Botswana agreement was ratified in 1988, and involves reciprocal duty free trade on all products grown, wholly produced, or manufactured wholly or partly from imported inputs subject to a 25 percent local content requirement. The Namibia agreement was in effect since 1992, subject to rules of origin which require at least 25 percent local content for manufactured goods. The Malawi agreement was implemented in 1995, with 25 percent local content. The Mozambique agreement was signed in January 2004, and became operational on 1 March 2005. Its objective is to eliminate tariff and nontariff barriers and also to cooperate in customs and trade promotion.

Zimbabwe is also a member of multilateral trade agreements. Zimbabwe is a member of Common Market for Eastern and Southern Africa (COMESA), which is a regional grouping of eastern and southern Africa states established in 1994. The main objective of COMESA is to achieve economic prosperity through regional integration, particularly in trade, customs, monetary affairs, transport, industry and agriculture. Zimbabwe also belongs to the Southern 
Africa Development Community (SADC) regional grouping.

1.1.3. Rebates, remissions and suspensions. Rebates and suspension of duty are granted in terms of the Customs and Excise Act Chapter: 23.02, Customs and Excise (General) Regulations (2001) and Customs and Excise (Suspension) (Amendment) Regulations (2010). A rebate of duty is a waiver of the duty payable.

According to statistics from the World Trade Organization on Zimbabwe, rebates and suspensions were granted to $23.3 \%$ of the total value of imports recorded in 2009. In 2010, rebates and suspensions amounted to $18.6 \%$ of the value of imports. The total revenue forgone in the implementation of these schemes was US\$ 253.8 million in 2009 and US\$ 318.3 million in 2010 (World Trade Organization, 2011). In both years, about $42.8 \%$ of all tariff lines recorded some concessionary imports. These figures make a strong case for tariff reform in Zimbabwe (WTO, 2011).

A duty drawback scheme has been in place in Zimbabwe since 1991. It provides for the refund of all duties paid on imported inputs used in the manufacturing or processing of goods for export (industrial drawback), and on unused goods exported in the form in which they were imported (same state drawback). An inward processing rebate scheme has been operational in Zimbabwe since 1992. It allows registered exporters to import or take out of bond, without payment of duty, goods destined for use in the processing of exports. Duties become payable if the finished goods have not been exported within 1 year (WTO, 2011).

A rebate of duty is granted on goods re-imported into Zimbabwe in the same condition as at the time of their exportation. Articles exported from Zimbabwe for the purpose of being repaired are subject to duty on re-importation, unless the repair was done free of charge in terms of a valid guarantee. When specified articles are imported or taken out of bond by a person engaged in mining, they are also exempted from paying customs duty. In 2011, after treasury was inundated by mining companies that sought to have their mining locations gazetted for purposes of benefiting from the rebate of duty on specific mining development operations, the rebate of duty was replaced by exemption from duty, whereby VAT is payable (Budget Statement, 2011).

Goods that are imported for prospecting and searching for mineral deposits are also exempted from paying duty. The goods should be imported by a person who has entered into a contract with the Government, i.e., a person with exploration title in order for one to qualify for the rebate. A rebate of duty may also be granted on goods imported in terms of an agreement entered in pursuant to a Special Mining Lease. A rebate of duty may also be granted on goods imported temporarily for an approved project. Lastily, a rebate of duty can be granted on goods for incorporation in the construction of approved projects.

Table 1 summarizes the rebates applicable in the mining sector upon importation. The table also shows the revenue that was forgone for the period 2009 to 2011 as a result of granting these rebates in the mining sector.

Table 1. Revenue forgone due to rebates in the mining sector (US\$ Millions)

\begin{tabular}{|c|l|c|c|c|}
\hline CPC & \multicolumn{1}{|c|}{ Nature of rebate } & 2009 & 2010 & 2011 \\
\hline 412 & $\begin{array}{l}\text { Specified goods for mining industry for } \\
\text { exploration }\end{array}$ & 2.0 & 1.9 & 0.4 \\
\hline 413 & $\begin{array}{l}\text { Goods imported for specified use in } \\
\text { mining industry }\end{array}$ & 5.8 & 13.1 & 5.2 \\
\hline 415 & Goods imported for petroleum exploration & 0.03 & 3.9 & 3.7 \\
\hline 429 & $\begin{array}{l}\text { Goods for incorporation for approved } \\
\text { projects }\end{array}$ & 7.5 & 20.3 & 9.2 \\
\hline 449 & $\begin{array}{l}\text { Goods imported for specific mining } \\
\text { development operations }\end{array}$ & 43.4 & 18.2 & 4.2 \\
\hline Total & & 58.8 & 57.4 & 22.7 \\
\hline
\end{tabular}

Source: Statistics extracted from ZIMRA Automated System of Customs Data (Asycuda).

In 2011, the rebate of duty on goods imported for mining development operations was replaced by an exemption from duty, whereby VAT was payable. Table 1 depicts very low revenue forgone in 2011 as compared to 2010 and 2009. It would be worthwhile to investigate why the revenue forgone is so low in 2011, as compared to previous years. From Table 1, it is clear that the Customs Procedure Code (CPC) that was negatively affected to a greater extent was 449 which relates to goods imported for specific mining development operations. The Minister's move to exempt only customs duty and make VAT payable had a huge impact on the CPC. Customs duty worth only US\$ 4.2 million qualified for a waiver under that rebate in 2011 , as compared to US\$ 43.4 million and US\$ 18.2 million in 2009 and 2010, respectively.

\section{Theoretical and empirical overviews}

2.1. Theoretical literature survey. Tax incentives have been classified into Value Added Tax, Corporate Income Tax, Property Tax, customs duty, tax holidays, depreciation allowances, grants, enhanced deductions and special initial allowances (Boura et al., 2006). The debate on the effects of tax incentives is well established, but still inconclusive. There are studies that claim that tax incentive effects are diverse (Hubbert and Pain, 2002). Other studies claim that they are immaterial (Head et al., 1995; Shah, 
1995), while, on the contrary, other studies claim that they are inexistent (Friedman et al., 1992). Some researchers argue that tax incentives are very difficult to justify, within the existing theoretical competition literature (Garcia-Mila \& Mcguire, 2002).

Easson \& Zolt (2002), OECD (2007) and Bolnick (2004) presented congruent arguments on the negative effects of tax incentives. Firstly, they can lead to revenue loss. They can also lead to revenue leakage through avoidance and evasion. In addition, tax incentives increase administrative costs for revenue collection agencies. They require applying different rules to different taxpayers, thereby inherently complicating the tax system. They can lead to economic distortions.

The effects of customs duty reductions and/or removals can be traced back to Adam Smith (Baldwin, 2009). He postulated that, when a nation exempts the goods of a country from duties, the merchants and manufacturers of the beneficiary country derive great advantage. Some papers focus on effects of tariff reductions on revenue performance, arguing that they lead to loss of revenues (Agbeyegbe et al., 2004; Cage \& Gadenne, 2014). Other researchers argue that the final effect of tariff reductions on revenue collections is not so obvious, but depends on the price elasticity of import demand (Cirera et al., 2011), initial structure of tariffs (Kowalski, 2005), tax system's administrative capabilities (Keen \& Ligthart, 2002). The impact of tariff policy is more complicated under constrained prices than under independent prices (Horst, 1971). Sogema (2013) argues that there are challenges in trying to assess tax exemptions in some African states due to unavailability and unreliability of data. However, customs duty exemptions have been harmful to African countries' economies, and should, therefore, be streamlined (ibid).

2.2. Empirical literature review. Some empirical studies relied on panel data regression analysis to determine the effects of tax incentives on various aspects. Agbeyegbe et al. (2004) analyzed the relationship between tariff reductions and revenues for a panel of 22 countries in sub-Saharan Africa in 19801996. They concluded that trade liberalization does not have a significant effect on overall tax revenue. Bora (2013) analyzed the effects of customs duty incentives on foreign direct investment in Ethiopia. Using a panel of ten sectors for the period from 1992 to 2012, she found out that customs duty exemptions had a negative impact on three sectors, namely construction, electricity and water supply. Hayakawa et al. (2015) examined the impact of free trade agreement schemes on import prices using firm level data from Thailand for the period 2007 to 2011. One essential finding of the study was that the use of free trade area schemes raised import prices.
There are empirical studies that have confirmed that tariff reductions led to customs revenue losses (Cage \& Gadenne, 2014; Mugano et al., 2013; Irwin, 1998). Southern \& Eastern Africa Trade \& Negotiation Institute (2012) cited the African Development Bank's report which estimated that Uganda lost at least $2 \%$ of its gross domestic product from tax incentives. The study concluded that the tax exemption policy in Uganda was substantially reducing the fiscal space and was, therefore, a serious challenge to revenue mobilization. Kigen (2011) analyzed the effects of tax incentives on exchequer revenue mobilization, using a sample of 25 firms in Kenya. The study findings were that tax incentives accounted for $0.6 \%$ of the total gross domestic product and 5\% of actual tax revenues collected per annum.

On the contrary, other studies do not confirm that tariff reductions automatically result in corresponding revenue losses. Samuel (2015) used a partial equilibrium model to perform simulations on Uganda's trade and revenue effects with the East Africa Community (EAC) countries, Democratic Republic of Congo and Sudan. The researcher concluded that the revenue implications of changes of applied tariff rates depend on the applied tariffs on imports. High rates show larger revenue effects, while low tariff rates show lower revenue effects. Mayende (2013) examined the effects of customs duty exemptions on firm performance in Uganda's manufacturing sector. Using panel data techniques for the period from 2000 to 2002, the study's main finding was that tax incentives had positive impact on firm performance.

\section{Research methodology}

3.1. Choice of methodology. The paper relies on both panel data and cross-sectional econometrics methodologies for analyzing customs duty incentives. Panel data methodology was chosen, because it involves two dimensions, a cross-sectional dimension $\mathrm{N}$, and a time series dimension $\mathrm{T}$. At first, the researcher expected that the computation of panel data estimates would be more complicated than the analysis of cross-sectional alone (where $\mathrm{T}=1$ ) or time-series data alone (where $\mathrm{N}=1$ ). However, the availability of panel data actually simplified the computation and inference. Panel data regression analysis was also favored, because the data were for a short period (six years) which was not very suitable for running regressions on time series data. Regressions for time series data usually require longer trends, i.e., data over longer periods of time.

Panel data gave the researcher a large number of data points $\left(\mathrm{N}^{*} \mathrm{~T}\right)$, increasing the degrees of freedom and reducing the collinearity among explanatory variables, hence, improving the efficiency of econo- 
metric estimates. It allowed control of heterogeneity of the cross-sectional units. It is expected that each cross-sectional unit has some intrinsic and immeasurable characteristics distinguishing it from others. Panel data also allowed better analysis of dynamic adjustments and it had increased precision of regression estimates (Wooldridge, 2002; Baum, 2006). Thus, longitudinal data allowed the researcher to analyze a number of important economic questions that could not be addressed using cross-sectional or time-series data.

Cross sectional regressions were run on the individual annual data sets as an alternative methodology. This was done with a view of comparing and confirming the plausibility of panel data regression results.

3.2. Data collection. While the study employed some of the variables used in previous studies, it digressed from previous studies by introducing panel data and cross sectional regression analysis at firm level and within a single specific sector. This rich firm level (micro) data was extracted from the ASYCUDA system that stores trade statistics for the Zimbabwe Revenue Authority. The panel data set used in the first model involved a sample of 35 companies in the Large Clients Office (LCO) for the period 2009 to 2014.

From the panel data set, the researcher also extracted cross-sectional data sets for each of the different specific years, and cross sectional regressions were run for comparability with the panel data results.

3.3. Models' specifications. Cross-sectional and panel data regressions were done in order to evaluate customs duty incentives' effects on revenue mobilization. The regression models are specified below:

Model 1 (panel data): effects of customs duty incentives on revenue mobilization

$c d_{i t}=\alpha_{0}+\beta_{1} v d p_{i t}+\beta_{2} c d r_{i t}+\beta_{3} v a t_{i t}+\beta_{4} r r_{i t}+U i+V i t$,

where:

$c d_{i t}$ is the variable capturing the individual firm's customs duty revenue; $\alpha_{0}$ is the intercept; $v d p_{i t}$ represents the value of imports for the individual firms; $c d r_{i t}$ is the customs duty incentives granted to the firms; $v a t_{i t}$ is the annual Value Added Tax paid on importation; $r r_{i t}$ is the royalty rate applicable to the individual firms; Ui denotes the individual firm specific effect; Vit is the orthogonal error term; $\beta_{1}$, $\beta_{2}, \beta_{3}$ and $\beta_{4}$ are parameters to be estimated. The data were converted to logs and the results would be interpreted as elasticities.

Model 2 (cross-sectional): effects of customs duty incentives on revenue mobilization $c d_{i}=\alpha_{0}+\beta_{1} v d p_{i}+\beta_{2} c d r_{i}+\beta_{3} v a t_{i}+\beta_{4} r r_{i}+U i$.

The description of the variables is the same as in Model 1.

3.4. Justification for the choice of variables and expected results. Customs duty (cd) is levied on imports at point of entry. Together with Excise Duty and VAT on imports, they indicate the revenue obtained from international trade, also referred to as trade tax. The customs duty variable was the dependent variable in the model.

When charging customs duty, customs administrations do not just consider the invoice value of the product. They factor in cost of freight and insurance to the invoice value. The Value for Duty Purposes (vdp) is the imports value. Ceteris paribus, the higher the value for duty purposes, the higher the customs duty. We, therefore, expected a positive and statistically significant relationship between customs duty and vdp.

Customs duty incentives (cdr) variable represents the customs duty incentive granted to the individual firms. A firm can be exempted from customs duty through preferential rates. These could be as per bilateral or multilateral trade agreements between nations. A firm can also be exempted from paying customs duty through the granting of rebates. The variable, therefore, indicates the amount of duty that was waived for the specific individual firms due to preferential rates and rebates. We expected a negative relationship between customs duty and customs duty incentives, in line with economic theory.

Value Added Tax on imports (vat) is another trade tax levied on imports. The base for VAT is Value for Tax Purposes (vtp). Value for Tax Purposes is calculated as Value for Duty Purposes (vdp) plus customs duty. We expected an increase in customs duty to have a corresponding increase in VAT in line with economic theory. On the contrary, Agbeyegbe et al. (2004) argue that where import values remain unchanged, a reduction in tariffs reduces revenue from trade taxes and can, consequently, reduce VAT on imports and Excise Duty.

Mineral Royalty rates (rr2) indicate a revenue outflow from the firm's coffers and the higher the rate of royalty, the higher the revenue outflow. A firm paying higher royalties may eventually import less than a firm that is being levied lower royalties. We, therefore, expected a negative relationship between the royalty rate and customs revenue, in line with economic theory.

3.5. Model estimations and results. 3.5.1. Results from panel data regression analysis. Descriptive statistics are a summary of the data used in the 
study. This study used 210 observations for the variables from the 35 firms under study and it is a balanced panel. Table 2 shows results from the panel data regression analysis. The data were converted into logarithms and the results would, thus, be interpreted as elasticities. L stands for the logarithms of the respective variables.

Table 2. OLS, FE \& RE Model 1 results with Dependent variable LVR

\begin{tabular}{|c|c|c|c|}
\hline Variables & OLS & Fixed effects & Random effects \\
\hline \multirow[t]{2}{*}{ Lvdp } & $0.5554^{\star \star \star}$ & $0.5446^{* \star *}$ & $0.5441^{* * *}$ \\
\hline & $(0.0705)$ & $(0.0702)$ & $(0.0685)$ \\
\hline \multirow[t]{2}{*}{ Lcdr } & $-0.1013^{* * *}$ & $-0.0921^{* * *}$ & $-0.0907^{\star * *}$ \\
\hline & $(0.3441)$ & $(0.0333)$ & $(0.0326)$ \\
\hline \multirow[t]{2}{*}{ Lvat } & $0.5902^{* * *}$ & $0.5837^{\star \star \star}$ & $0.5873^{\star * *}$ \\
\hline & $(0.0671)$ & $(0.0651)$ & $(0.0639)$ \\
\hline \multirow[t]{2}{*}{ Lrr2 } & -0.0346 & & -0.0473 \\
\hline & $(0.0839)$ & & $(0.1568)$ \\
\hline R-squared & 0.89 & 0.90 & 0.90 \\
\hline F-statistic & $311.25^{\star \star \star}$ & $356.38^{\star \star \star}$ & \\
\hline Wald chi 2 & - & - & $1162.92^{\star \star \star}$ \\
\hline No. of obs & 141 & 141 & 141 \\
\hline
\end{tabular}

Key: $* * *$ significant at $1 \%$, standard errors in parentheses

3.5.2. Results from cross-sectional regression analysis. A number of cross-sectional regressions were run to model the effect of customs duty incentives. The preferred estimated equation's results are presented below:

\begin{tabular}{|l|c|}
\hline \multicolumn{1}{|c|}{ Variables } & Cross-section regression result \\
\hline vdp & 0.002 \\
\hline & $(0.7)$ \\
\hline cdr & -0.41 \\
\hline & $\left(4.11^{\star \star *}\right)$ \\
\hline vat & 12.77 \\
\hline & $\left(0.47^{\star \star *}\right)$ \\
\hline rr2 & -0.13 \\
\hline & $\left(-1.84^{* *}\right)$ \\
\hline R-squared adjusted & $0.88^{\star \star *}$ \\
\hline F-statistic & $62.39^{\star \star *}$ \\
\hline No. of obs & 35 \\
\hline
\end{tabular}

Key: $* * *$ significant at $1 \%, * *$ significant at $5 \%$, standard errors in parentheses.

The adopted cross-sectional regression model was overally significant, with an adjusted R-squared of $88 \%$ and an F-statistic of 62.39 . Cross-sectional regression results further confirmed the negative and statistically significant relationship between customs duty revenues and customs duty incentives. The tax incentive variable (cdr) was significant at $1 \%$. Just like in the panel data regression results, the vat variable was also significant at $1 \%$. Explanations of these variables are similar to those under panel data regression analysis.

\section{Findings, policy recommendations and con- clusion}

4.1. Discussion of findings. Three variables in Model 1 are statistically significant using OLS, Fixed Effects and the Random Effects models. The R-squared of the adopted model is quite high, 0.89 for OLS and 0.90 for both the Fixed Effects and Random Effects. This means that about 90 percent of the variation in the dependent variable is explained by the variations in the explanatory variables. Thus, the whole model is statistically significant.

The Value for Duty Purposes (vdp) variable was statistically significant at all levels for all three models, namely, OLS, FE and RE. The variable was positively related to the customs revenue variable. This finding is consistent with economic theory that Customs duty increases in line with increases in the value of imports. This implies that policies that are geared towards improving import values can have a positive effect on customs revenue mobilization. Agbeyegbe et al. (2004) argue that where import values remain unchanged, a reduction in tariffs reduces revenue from trade taxes.

The customs duty incentive variable (cdr) was negatively related to the customs duty revenue variable (cd), for the Random Effects, Fixed Effects and Ordinary Least Squares models. The variable was also statistically significant at all levels of inference. This finding is consistent with the results in Cage \& Gadenne (2014) study. The cited study confirmed that tariff removals and/or reductions had larger and longer lived decreases in revenues for developing countries. The finding is also consistent with economic theory.

Value Added Tax on imports (vat) was also statistically significant at all levels and positively related to the customs duty variable. Normally, we would expect an increase in Customs duty to have a negative effect on VAT on imports, since they are both costs for the same importer (Agbeyegbe et al., 2004). However, in reality, the two were not negatively related. This was due to the fact that both trade taxes depend on the value of imports. If imports value increase for dutiable commodities, the result will be an increase in both VAT and customs duty. Customs duty is levied on VDP while VAT on imports is levied on VTP (i.e., VDP + customs duty). There is a strong relationship between these two bases.

The royalty rate $(\mathrm{rr} 2)$ variable was the only variable that was not statistically significant in all the three models, although it had the expected sign. The variable was negatively related to the customs duty variable, in line with economic theory. The results imply that neither an increase nor reduction in the 
rate of mining royalties affect trade taxes, like customs duty. The result could have been different, if the royalty rate was reduced or increased for domestic taxes, like mineral royalties. Domestic tax incentives may show different results from trade tax incentives, depending on the revenue head to influence.

4.2. Policy recommendations. There is a need to streamline the rebates granted to importers of goods meant for use in the mining sector. Our empirical investigation revealed that Government has been losing significant revenue as a result of granting tax concessions in the mining sector. This revenue loss is not in tandem with benefits derived in the mining sector.

It is also recommended that ZIMRA and other relevant arms of Government be vigilant in identifying current beneficiaries of these incentives/rebates. Post clearance audits should be intensified in order to assess whether the rebates are not being abused. There is also a need to confirm whether the beneficiaries are making any significant contributions to other tax heads like Corporate Income Tax, VAT on Local Sales and Pay as You Earn. In cases where beneficiaries of Customs duty incentives are not contributing to other tax/revenue heads, audits should be instituted and severe penalties imposed for non-compliers.

A retrospective tax incentive or rebate system may also be considered whereby for an entity to be granted certain incentives/rebates, they need to have met certain economic benchmarks like number of jobs created, level of production promised, foreign exchange earned and repatriated, infrastructure development and others, for them to then claim the incentive/rebate value.

Lastly, in the event that Government considers granting new incentives in the future, Government should evaluate the status quo of the current and previous incentives to determine the merits of new ones and their potential benefits to the economy.

Conclusion. Empirical investigations carried out using a sample of 35 firms in Zimbabwe's mining sector, confirmed that Customs duty incentives were significantly eroding Customs duty revenues. There is an urgent need for policy makers to streamline Customs duty incentives currently applicable in the mining sector, in order to meet Government's objective of increasing trade tax revenues.

\section{References}

1. Agbeyegbe T., Asegedech W. \& Stotsky J.G. (2004). Trade liberalization, exchange rate changes, and tax revenue in Sub-saharan Africa, International Monetary Fund, 4(173), pp. 1-9.

2. Baldwin, R. (2009). The rise of the preferential trade and the classic analysis of its input, Geneva: s.n.

3. Baum, C. F. (2006). An introduction to modern econometrics using stata s.1.: College Station, Texas.

4. Bolnick, B. (2004). Effectiveness and economic impact of tax incentives in the SADC region, Arlington Virginia, U.S.A: Nathan Associates Inc.

5. Bora, S. (2013). The effectiveness of tax incentives in attracting foreign direct investment in Ethiopia. The Hague: Institute of Social Studies.

6. Boura, P., Koumanakos, E. \& Georgopoulos, A. (2006). Tax incentives and financial reporting of Greek firms: an emprical enquiry, Journal of Business and Economic Anthology, 1, pp. 87-94.

7. Cage, J. \& Gadenne, L. (2014). [Online] Available at: http://d.repec.org/n?u=Repec:spo:wpman:info:hdl: 2441/4icc4hr7684k8f6u7csmfuve2\&r:pub_[Accessed 21 July 2015].

8. Chamber of Mines of Zimbabwe (2013). Chamber of Mines of Zimbabwe. [Online] Available at: http://www.chamberofminesofzimbabwe.com [Accessed August 2014].

9. Cirera, X., Willenbockel, D. \& Lakshman, R. (2011). What is the evidence of the impact of tariff reductions on employment and fiscal revenue in developing countries? s.l.: University of London.

10. Easson, A. \& Zolt, E. (2002). Tax incentives. World Bank Institute.

11. Friedman, J., Gerlowski, D. \& Silberman, J. (1992). What attracts foreign multinational corporations? Evidence from branch plant location in the United States, Journal of Regional Science, 32(4), pp. 403-418.

12. Garcia-Mila, T. \& Mcguire, T. (2015). Tax incentives and the city. [Online] Available at: http://crei.cat/people/gmila/GALLEY.PDF [Accessed 21 July 2015].

13. Harger, K. \& Ross, A. (2014). Do capital tax incentives attract new business? Evidence across industries from the new markets tax credit. Morgantown: Department of Economics, West Virginia University.

14. Hayakawa, K., Luksanapanyakul, N. \& Urata, S. (2015). Firm-level impact of free trade agreements and import prices. ERIA Discussion Papers, April. Volume 33.

15. Horst, T. (1971). The theory of the multinational firm: optimal behaviour under different tariff and tax rates, Journal of Political Economy, 79(5), pp. 1059-1072.

16. Hubbert, F. \& Pain, N. (2002). Fiscal incentives, European integration and the location of foreign direct investment. The Manchester School, June.Volume 3.

17. Irwin, D. (1998). Higher tariffs, lower revenues? Analysing the fiscal aspects of the "Great Tariff Debate of 1888 ". The Journal of Economic History, March, 58, pp. 59-72.

18. Keen, M. \& Ligthart, J. (2002). Coordinating tariff reduction and domestic tax reform. Journal of International Economics, Volume 56, pp. 490-507. 
19. Kigen, T. (2011). The effects of tax incentives on exchequer revenue mobilization: a case of the top 25 taxpayers in Kenya. [Online] [Accessed 24 July 2014].

20. Kowalski, P. (2005). Impact of changes in tariffs on developing countries' government revenue. OECD Trade Policy Working Papers, April. Volume WP No.18.

21. Makoni, E., Tsikirayi, C. \& Mandizha, E. (2013). To charge or not charge customs excise duty on digitized products: an assessment of the Zimbabwe Revenue Authority (ZIMRA) potential revenue losses through duty exemptions on digitized goods, International Journal of Education and Research, August, 1(8).

22. Mayende, S. (2013). The effects of tax incentives on firm performance: Evidence from Uganda, Journal of Politics and Law, September, 6 (4).

23. Mugano, G., Brookes, M. \& Le Roux, P. (2013). Estimating the impact of COMESA Customs Union on Zimbabwe using Tariff Reform Impact Simulation Tool (TRIST) African Journal of Management, 7(38), pp. 4000-4010.

24. Samuel, G. (2015). Uganda's trade revenue effects with the EAC countries, DRC and Sudan, Modern Economy, 6, pp. 338-357.

25. Shah, A. (1995). Fiscal Incentives for investment and innovation. s.1.: Oxford.

26. Sogema, C. (2013). Tanzania per tax exemption study, s.l.: Prepared for Ministry of Finance, Tanzania.

27. Southern \& Eastern African Trade Information \& Negotiations Institute (2012). Tax exemptions implications on socio-economic development. s.l.: Southern \& Eastern African Trade Information \& Negotiations Institute.

28. Southern African Development Community (2002). Memorandum of Understanding on Taxation. s.1.: Southern Africa Development Community.

29. Wooldridge, J. (2002). Econometric analysis of cross-section and panel data. Cambridge: MIT Press.

30. World Trade Organization (2011). Trade Policy Review- Zimbabwe 2011, s.1.: World Trade Organization.

31. Zimbabwe Revenue Authority, n.d. Zimbabwe Revenue Authority. [Online] Available at: http://www.zimra.co.zw. 